\title{
Production and evaluation of sweet spreadable goat cheese
}

\author{
Neamah Raef Attalla ${ }^{1}$, Eman Fouad Mohamed ${ }^{1}$, Wael Helmy Moussa El-Reffaei ${ }^{2,}$, \\ Nemat Ibrahiem Bassyoni ${ }^{2}$
}

${ }^{1}$ Animal Production Institute, Agric. Res. Centre, Dokki, Giza, Egypt

${ }^{2}$ Regional Centre for Food and Feed (RCFF), Agric. Res. Centre, Giza, Egypt

\section{Email address:}

waillh@hotmail.com(EL-Reffaei W. H. M.)

\section{To cite this article:}

Neamah Raef Attalla, Eman Fouad Mohamed, Wael Helmy Moussa El-Reffaei, Nemat Ibrahiem Bassyoni. Production and Evaluation of Sweet Spreadable Goat Cheese. International Journal of Nutrition and Food Sciences. Vol. 3, No. 2, 2014, pp. 79-90.

doi: $10.11648 /$ j.jinfs.20140302.20

\begin{abstract}
Goat milk is cheap and contains adequate quantities of iron, folate, vitamins $\mathrm{C}$ and $\mathrm{D}$, thiamin, niacin, vitamin B6, and pantothenic acid to meet an infant's nutritional needs. The fat globules are smaller and easier to digest. New formula of goat cheese is formulated to develop a new economic producer contain a nourished flavored cheese. Fortification goat cheese with caramel, cocoa and cocoa with walnuts are corresponding high quality protein ingredient for sweet spreadable cheese. The $\omega-6 / \omega-3$ ratio was at level $6.00,7.7$ and 4.7 contribute to caramel sweet cheese, cocoa sweet cheese, and cocoa $\&$ walnut cheese, respectively. Methionine + cysteine and follows by tryptophan were the most limiting essential amino acids, in these ingredients. Different formulas' goat cheese could be improved their amino acids scores. The highest cohesiveness value was recorded for of cocoa and walnut sweet cheese treatment followed by caramel spreadable sweet cheese and cocoa spreadable sweet cheese appreciable differences between them. Revealing to microbiologic assays, sweet cheese samples is stable during storage against poising bacteria and other microorganisms. Conclusion, a fortified sweet goat cheese with cocoa and walnut could be regards as Egyptian economic products and nourished for human consumption especially for children feeding.
\end{abstract}

Keywords: Caramel, Goat Spreadable Cheese, Cocoa, Essential Amino Acids, Fatty Acids, Walnut, $\omega-6 / \omega-3$ Ratio

\section{Introduction}

Cream cheese is a cheese of the semi-soft, fresh acid curd variety, obtained by slow quiescent acid gelation of milk. It's have a clean, fresh, butter-like lactic flavor and a soft/semisoft smooth creamy consistency with a texture that ranges from spreadable to short and brittle, depending on composition (e.g. fat content), manufacturing conditions (e.g. degree of heating and shear during curd treatment), processed cheese affecting the rheological behavior of the molten mass during processing and the texture of the final product [1].

However, cream cheese and related varieties as a group differ significantly $[2,3]$ in terms of gelatin mode, make procedure, flavor and texture. While, flavor of ripped (biochemical changes e.g. glycolysis) cheese is depend on the development of the attendant sensory characteristics. During the manufacture of these products, the curd is heated to $80^{\circ} \mathrm{C}$, hot packed and cooled to $<8^{\circ} \mathrm{C}$ to allow fat crystallization and product sticking.

Owing to the high temperature, microbial and enzymatic activities are low. These cheeses may be classified as unripe varieties, being ready for consumption within a few days after manufacture [4].Spreadable processed cheese has higher moisture content than other processed cheese. The standard American FDA set was moisture content 44\%$60 \%$, fat content $20 \%$, and natural cheese content no less than $51 \%$. And allowed adding various ingredients, greatly lowered the cost of spreadable processed cheese which made greatly pleased the public and also improved nutritional quality of spreadable creamy cheese. Thanks to the heating, emulsifying, and sterilization processing, the flavor of processed cheese is improved [5].

For the evaluation of the viscoelastic behavior of processed cheese and the way that it is affected by different factors, dynamic rheology has mainly been used [6]. Moisture acted as a plasticizer and fat as a lubricant both contributing to a more liquid-like behavior of the samples. 
In contrast, proteins reinforced the strength of the threedimensional matrix leading to processed cheeses with more solid-like behavior [7]. Cocoa products have a high food value because of the large proportion of fat, carbohydrates, and protein. Cocoa products are eaten mainly because they are liked, by young and old, owing to their attractive flavors and appearance which give pleasure in eating [8].The nutritional parameters of cocoa are determined largely by the chemical composition of the material. The energy contribution to daily diets is dependent on the quantum of proteins, carbohydrates and fats in the cocoa product and its corresponding digestibility coefficient [8]. Cocoa powder is mainly used for low calorie food products. The minerals present in cocoa powder are important for their nutritional value. Cocoa is added as flavor enhancement. It also contains various psychoactive compounds, such as the bromine, caffeine, serotonin, histamine, tryptophan, trytamine, tyramine, phenylethylamine, octopamine and anandamide [9]. The obromine and theophylline, as well as caffeine, all found in this plant, are used as a diuretic, stimulant and also, in modern medicine, as an antiasthmatic [10].

Walnuts (Juglans regia L.) are widely distributed all over the world; these fruits are increasing interest as a healthy foodstuff because their regular consumption has been reported to decrease the risk of coronary heart disease [11]. In view of the increasing production of walnut globally, there is a need for an increased utilize of the walnut, especially the nutritious walnut kernel. The walnut kernel is of high food value with $65 \%$ oil and $18-24 \%$ protein contents, and it can be used as an adjunct in chocolate and utilized as ingredient of many foodstuffs such as bakery products to enhance the nutrition value of products [12]. Walnuts oil is major product of walnut production and is one of the important special oils used for salad dressing and cooking [13]. Besides walnut oil and protein, Walnut contain $12-16 \%$ carbohydrates, $1.5-2.0 \%$ cellulose, $1.7 \sim 2.0 \%$ mineral [14].

The major volatiles were aldehydes and hydrocarbons, produced mainly through the oxidative pathways. nPentane, nonanal, and 2,4-decadienal were predominant in walnut oils. Walnut oils were abundant in PUFA (linoleic + linolenic) the highest percentages of linoleic acid were found in walnut oils (more than 52\%), Linoleic was the major FA in walnut oil and most of the fat-derived flavors arose from it as reported by [15]. As a by-product of oil production, walnut protein products are therefore being considered as an additional source of plant protein for use in human food products. Walnuts nutrient composition has been investigated by [16].

Goat milk is cheap, available in Egypt production and more nourished for children; it is containing a higher ratio of nutrient materials than cow's milk. To increase palatability of spread goat cheese and offer an economic formula.

The objective of this study was corresponding to valuable the goat milk uses in formulated cheese more favorable by children, to improving the nutritional and quality of flavored spreadable goat cheese. By evaluating the nutritional, rheological, microbiological and sensory parameter of sweet spreadable goat cheese fortified with caramel, cocoa and cocoa with walnuts.

\section{Materials and Methods}

\subsection{Ingredient}

Milk: fresh goat's milk was obtained from the herd Sakha Animal Production Research Station, Animal Production Research Institute, Ministry of Agriculture. It contained $3.15 \%$ protein, $3.6 \%$ fat, $0.7 \%$ ash and $12.3 \%$ total solids. Other ingredients such as cocoa powder, sugar and walnuts were purchased from local market in Giza. Commercial yoghurts starter (Streptococcus salvarius subsp.thermophilus and Lactobacillus delbrueckii subsp.bulgaricus) were obtained from Chr.Hansen's Lab, Copenhagen Denmark.

\subsection{Preparation of Sweet Spreadable Goat Cheese}

Raw goat milk was subjected to a heat treatment at $72{ }^{\circ} \mathrm{C}$, added emulsifier $(0.5 \%)$, then raise the temperature to $95^{\circ} \mathrm{C}$ for $20 \mathrm{~min}$, and cooling to $40: 45^{\circ} \mathrm{C}$, starter culture was added to milk $(3.0 \%)$ and then incubated until $\mathrm{pH}$ reach $4.6 \%$. After yoghurt gel forms, it was kept for 4 hours at $5 \pm 1{ }^{\circ} \mathrm{C}$. Yoghurt was transferred to a steel container with a flat bottom under which a fire has been set. Yoghurt was transferred to a steel container with a flat bottom under which a fire has been set. Yoghurt was stirred continuously until it boils, then the curd was drained to remove whey by using cloth bag. After removing whey, curd was washing by water which boiling in previous, to decrease the acidity. Let the curd drained whey for 10-12 $\mathrm{h}$ in a hanging cloth bag. Following the curd was divided to three portions:

First portion as caramel sweet spreadable goat cheese, put sugar $(20 \%)$ from the weight of the curd into a pot and cook on low heat, stirring with a wooden spoon until get big bubbles, when the sugar changes color (becomes caramel), consistency, mixed with the first portion from the curd carefully with caramel till the mixture completely homogenized, take it off the heat and carefully pour into sterilized bottles.

Second Portion as Cocoa Sweet Spreadable Goat Cheese: Mix the second portion from the curd with $20 \%$ sugar, $10 \%$ cocoa from the weight of the crud and heat the mixture in bath water to $85^{\circ} \mathrm{C}$ for 15 minutes. Stirring with wooden spoon, then, take the mixture off the heat and carefully pour into sterilized bottles.

Third Portion as Cocoa with Walnuts Sweet spreadable Goat Cheese: Mix the third portion from the curd with $20 \%$ sugar, $10 \%$ cocoa from the weight of the curd. Heat the mixture in water path to $85^{\circ} \mathrm{C}$ for 15 minutes. $10 \%$ walnuts (crushed) were mixed with the crud, and then pour the mixture into sterilized bottles. 
The treatments Sweet Spreadable Goat Cheeses fortified with flavors stored at room temperature and analyzed chemically, microbiologically, organoleptically and estimated biologically evaluations.

\subsection{Amino Acids Profile}

For the determination of amino acids, samples were performed according to the method of [17]. Oxidation with performic acid, to protect methionine and cystine from distraction during acid hydrolysis with $6 \mathrm{M} \mathrm{HCL}$ ) were carried out in closed conical flash for determine all amino acid other than tryptophan. Sample of 20-30 mg weighted in conical flask and $5 \mathrm{ml}$ of performic acid was added. The flask was closed and placed in ice water bath for $16 \mathrm{hr}$. Sodium metabisulfate and $25 \mathrm{ml}$ HCL $6 \mathrm{~N}$ were added to the oxidized mixture. The flask was placed in an oven at $110^{\circ} \mathrm{C}$ for $24 \mathrm{hr}$. The flask was then opened and all removed by evaporating samples to dryness in rotary evaporator. A suitable volume of sodium citrate puffer $(\mathrm{pH}$ 2.20) was added to the dried film of hydrolyzed sample. After all soluble material completely dissolved, the samples analyzed for amino acids using Eppendorf LC 3000 (EZ Chrom, software used for data collection and processing). The results were calculated as percentage of total crude protein. Determinate tryptophan was carried out using method described by [18] after hydrolysis of samples with barium hydroxide. All amino acids were reported as $\mathrm{g}$ of amino acids / $16 \mathrm{~g}$ Nitrogen.

\subsection{Nutritional Quality Assessments}

The nutritional parameters for Caramel, Cocoa and Cocoa with walnuts sweet spreadable goat cheese were determined in the basis of amino acid profiles such the following:-

Chemical score (CS): of amino acids was calculated by using professional pattern amino acid of [19]. Chemical score (CS) \% and first, second and third limiting amino acids. Calculations of amino acid score as follows in equation no (1):

Amino acid score $(\mathrm{CS})=\mathrm{mg}$ of amino acid in $1 \mathrm{gm}$ tested protein / $\mathrm{mg}$ of amino acid in requirement pattern $\times 100$ (1)

Essential Amino Acid Index (EAAI \%) was performed by [20] using the amino acid pattern of whole egg protein according to [21] as reference protein and follows formula: expressed by the amino acids results were expressed as $\mu$ moles of amino acid per gram of flour samples ( $\mu$ mole $/ \mathrm{g}$ ) and as grams per $100 \mathrm{~g}$ determined amino acid for reference egg protein using equation No (2).

$$
\sqrt[n]{\alpha \alpha 1 / A A 1 \times \alpha \alpha 2 / A A 2 \ldots \ldots \ldots .} \times \frac{\times \alpha \alpha 11 / A A 11}{2}
$$

Predicted of protein efficiency ratio (P-PER): The prediction was performed by regression equation No (3) developed by [22].

$$
\text { P-PER }=-0.468+0.454(\text { Leu })-0.105 \text { (Tyr) }
$$

\subsection{Rheological Parameters by Texture Profile Analysis (TPA)}

\subsubsection{Texture Profile Analysis (TPA)}

TPA is a method to evaluate the sensory properties. Texture was determined by a universal testing machine (Cometech, B type, Taiwan) provided with software. An aluminum $25 \mathrm{~mm}$ diameter cylindrical probe was used in a (texture Profile Analysis) (TPA) double compression test to penetrate to $30 \%$ depth, at $1 \mathrm{~mm} / \mathrm{s}$ speed test. Firmness $(\mathrm{N})$, gumminess $(\mathrm{N})$, chewiness $(\mathrm{N})$, adhesiveness (N.s), cohesiveness, springiness and resilience were calculated from the TPA graphic. Both, springiness and resilience, give information about the after stress recovery capacity. But, while the former refers to retarded recovery, the latter concerns instantaneous recovery (immediately after the first compression, while the probe goes up). Texture determinations were carried out in $(40 * 40) \mathrm{mm}$-sized samples. Cohesiveness $=$ extent to which sample could be deformed prior to rupture; Springiness $=$ ability of sample to recover to its original shape after the deforming force was removed; Gumminess $=$ force to disintegrate a semisolid meat sample for swallowing (hardness $\times$ Cohesiveness); and Chewiness $=$ work to masticate the sample for swallowing (springiness $\times$ gumminess) were determined as described by [23].

\subsection{Microbiological Assessment}

Total bacterial count, total coli form count, yeast \&molds, Spore form, Staphylococcus aureus, Bacillus cerues and Listeria monocytogenes were determine according [24].

\subsection{Sensory Evaluation}

Sensory evaluation of sweet spreadable goat cheese was assessed by 15 panel members of Dairy Science Department Production, Research Institute, Dokki, Giza for aroma \& flavor (40 points), body \& texture (40 points) and outer appearance (20 points) as reported by [1].

\subsection{Statistical Analysis}

Results were performed in triplicate and expressed as mean \pm SD. Data analysis was conducted by using Oneway analysis of variance ANOVA to evaluate the significance in the difference between means. Least significant difference was used for comparing mean values. Statistical analyses were performed using JMP V6 software from SAS [25]. A value of $p<0.05$ was considered to indicate statistical significance.

\section{Results and Discussion}

Table 1 shown the chemical composition of three formulas of sweet spreadable goat cheeses which were fortified by nourished flavoring comparison with base materials of natural goat milk. The high moisture content is 
recorded in native goat milk $81.13 \% \pm 0.20$, while the

52.80 up to $58.60 \%$. moisture content among different formula was ranged from

Table 1. Chemical composition for different formula of sweet spreadable goat cheese fortified with different flavors

\begin{tabular}{|c|c|c|c|c|c|c|c|c|}
\hline \multirow{2}{*}{$\begin{array}{l}\text { Chemical } \\
\text { composition }\end{array}$} & \multirow{2}{*}{ Moisture } & \multirow{2}{*}{ Protein } & \multirow{2}{*}{ Ash } & \multirow{2}{*}{ Fat } & \multirow{2}{*}{ Fiber } & \multicolumn{2}{|c|}{ Mineral content } & \multirow{2}{*}{ PH } \\
\hline & & & & & & Calcium \% & Phosphorus mg/kg & \\
\hline Goat milk & $81.13 \pm 0.20$ & $3.43 \pm 0.11$ & $0.47 \pm 0.25$ & $4.65 \pm 0.32$ & $4.22 \pm 0.12$ & $0.175 \pm 0.12$ & $0.103 \pm 0.12$ & $6.27 \pm 0.10$ \\
\hline Walnut & $3.84 \pm 0.12$ & $19.24 \pm 0.24$ & $1.92 \pm 0.19$ & $56.95 \pm 0.10$ & $3.24 \pm 0.24$ & & & \\
\hline $\begin{array}{l}\text { Caramel spreadable } \\
\text { sweet cheese }\end{array}$ & $56.00 \pm 0.01$ & $16.30 \pm 0.21$ & $1.01 \pm 0.05$ & $8.44 \pm 0.31$ & $8.14 \pm 0.1$ & $0.77 \pm 0.08$ & $0.738 .9 \pm 0.01$ & $3.32 \pm 0.16$ \\
\hline $\begin{array}{l}\text { Cocoa sweet } \\
\text { spreadable goat } \\
\text { cheese }\end{array}$ & $58.60 \pm 0.10$ & $16.46 \pm 0.21$ & $0.66 \pm 0.11$ & $8.46 \pm 0.09$ & $6.66 \pm 0.14$ & $1.40 \pm 0.10$ & $0.1198 \pm 0.41$ & $4.80 \pm 0.112$ \\
\hline $\begin{array}{l}\text { Cocoa with walnuts } \\
\text { sweet spreadable } \\
\text { goat cheese }\end{array}$ & $52.80 \pm 0.11$ & $16.64 \pm 0.15$ & $1.09 \pm 0.17$ & $12.48 \pm 0.19$ & $8.34 \pm 0.02$ & $1.82 \pm 0.14$ & $1.9102 \pm 0.17$ & $4.85 \pm 0.18$ \\
\hline
\end{tabular}

* Results: mean values \pm S.D (Standard Deviation).

Table 2. Fatty Acids Composition (\%) of spreadable sweet cheese fortified by flavors and nutritional formula

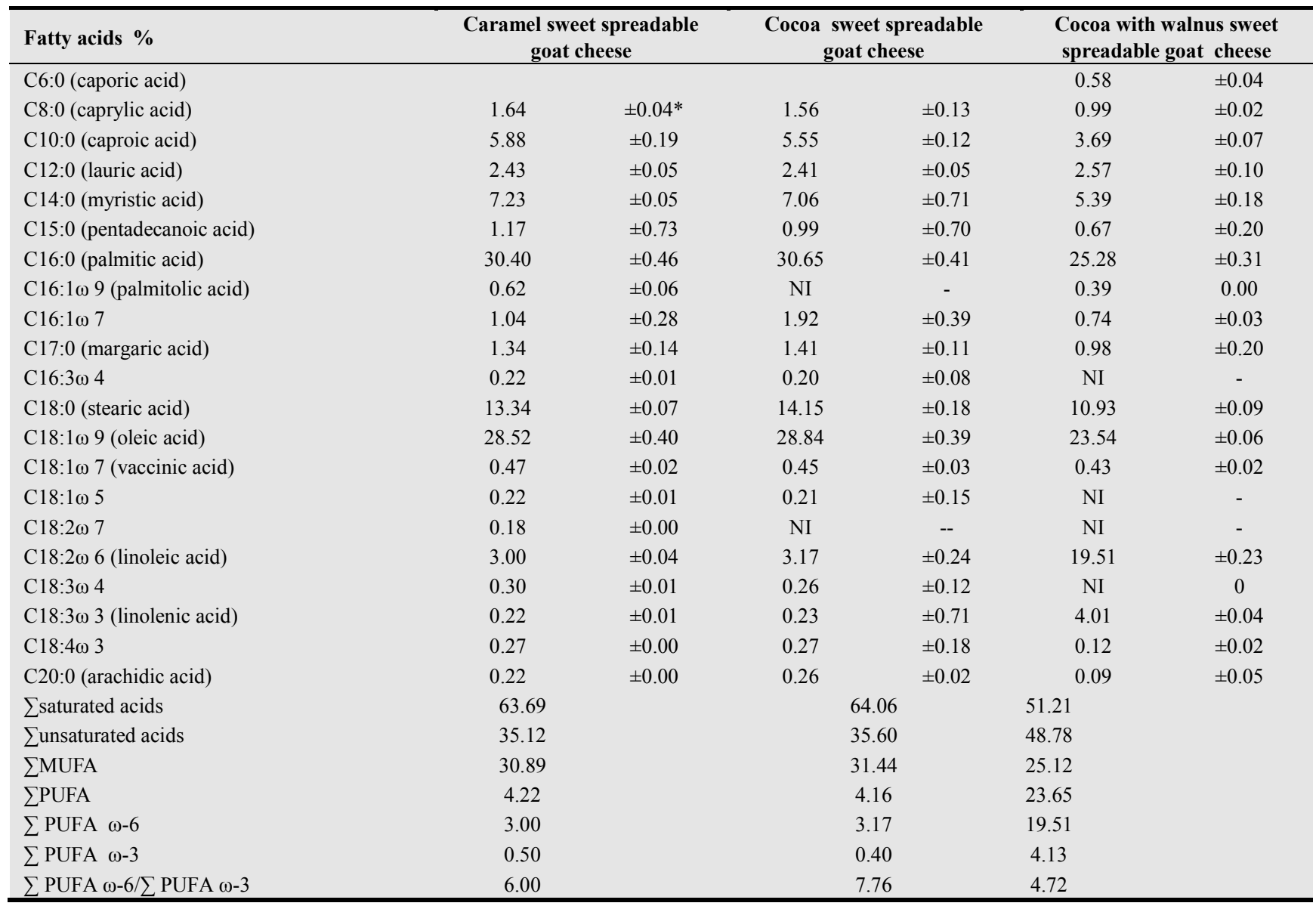

$*$ Mean values $(\mathrm{n}=3) \pm \mathrm{SD}$

The goat milk has a superior nutritive value because it is more digestible as a softer, more easily broken down coagulant is formed in the stomach and thus the protease in stomach contact more readily, thus favoring digestibility [26]. The fat content in goat milk is lower than determined in three current cheese formula $4.65 \% \pm 0.32$. Meanwhile, the caramel, cocoa and cocoa with walnuts sweet spreadable goat cheese was containing a fairly duplicate ratio of fat as $8.44 \pm 0.31,8.46 \pm 0.09$ and $12.48 \% \pm 0.19$, respectively. This improvement in fat and protein content is generally provides a high nutritional of three formulated sweet spreadable goat cheese, it's could be considered as an add value of goat cheese. Notably, their nutritional value of component flavored goat cheese, but also for its sensory acceptability for children foods. This is agreed by [27] the consumption of goat milk produces a better protein efficiency ratio and food conversion efficiency values, particularly in rats with intestinal resection, together with a 
higher nutritive utilization of protein. $\mathrm{pH}$ value is indirectly affected in the microstructure and texture as well as sensory evaluation of cheese. The most appropriate processing $\mathrm{pH}$ was $3.32-6.27 . \mathrm{pH}$ value affected on the number of charges of protein surface and then affected protein hydration, ion composition, strength and hydrophobic .

And it also had a great influence on the sample's texture and microstructure [28] .Therefore, $\mathrm{pH}$ value was one of the main indexes influenced processed cheese's hardness viscosity and smearing work. Table 2 showed that the addition of caramel exerted a notable effect on $\mathrm{pH}$ of caramel cheese from $6.27 \pm 0.10$ in goat milk into $3.32 \pm 0.16$. Different of ingredient added into sweet spreadable goat cheese had gradually decreased $\mathrm{pH}$ gradually comparing to base of goat milk. Quite similar decreases in $\mathrm{pH}$ could be occurred in $\mathrm{pH}$ of cocoa and cocoa with walnuts sweet spreadable goat cheese by 4.80 and 4.85 , respectively.

\subsection{Fatty Acids Composition}

Mean values and standard deviations of fatty acid composition for analying sweet spreadable fortified goat cheese samples are shown in Table (3). The fatty acids profile is composed by twenty one fatty acids, with all samples presenting a similar constitution, although with some variation (Table 3). Palmitic acids (C16:0) was the most abundant fatty acids in either caramel or cocoa cheese, ranging from $30.40 \% \pm 0.46$ in caramel cheese and $30.65 \%$

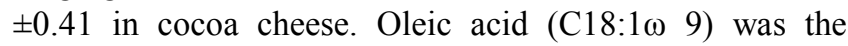
second in order of importance varying between $28.52 \%$ \pm 0.40 (in caramel cheese) and $28.84 \% \pm 0.39$ (in cocoa spreadable cheese), follows by stearic acid (C18:0) which representatives from 13.34 in caramel cheese by $14.15 \%$ \pm 0.18 in cocoa spreadable cheese. For the remaining fatty acids only myristic acid (C14:0) (7.23 $\pm 0.05-7.06 \%$ $\pm 0.71)$, caproic $(\mathrm{C} 10: 0)(5.88-5.55 \%)$, and linoleic acid $(\mathrm{C} 18: 2 \omega 6)(3.00 \pm 0.04-3.17 \% \pm 0.24)$ were presented in considerable amounts in caramel cheese and cocoa spreadable cheese. [29] reported that, the linolenic acid and palmitic acid were the most important fatty acids.

Table 3. Amino acids composition ( $g$ AA /16g nitrogen) of sweet spreadable goat cheese fortified with different flavors

\begin{tabular}{|c|c|c|c|c|c|c|c|c|}
\hline Amino acid & $\begin{array}{c}\text { Cocoa } \\
\text { Powder }\end{array}$ & Walnut & Goat Milk & $\begin{array}{c}\text { Caramel } \\
\text { sweet } \\
\text { spreadable } \\
\text { goat cheese } \\
\end{array}$ & $\begin{array}{c}\text { Cocoa sweet } \\
\text { spreadable } \\
\text { sweet goat } \\
\text { cheese } \\
\end{array}$ & $\begin{array}{c}\text { Cocoa with } \\
\text { walnut } \\
\text { sweet } \\
\text { cheese } \\
\end{array}$ & $\begin{array}{c}\text { FAO/ } \\
\text { WHO/UN } \\
\text { U 1985 }\end{array}$ & $\begin{array}{c}\text { Egg } \\
\text { amino } \\
\text { acids } \\
\text { reference }\end{array}$ \\
\hline \multicolumn{9}{|l|}{ Essential amino acids } \\
\hline Tyrosine (Tyr) & 3.42 & 3.60 & 4.56 & 4.23 & 4.74 & 3.97 & - & 4.20 \\
\hline Phenylalanine (Phe) & 4.79 & 3.25 & 5.16 & 5.46 & 5.01 & 4.87 & - & 5.70 \\
\hline Total aromatic amino acids & 8.20 & 6.85 & 9.72 & 9.69 & 9.75 & 8.84 & 6.00 & 9.90 \\
\hline Threonine (Thr) & 4.56 & 1.78 & 4.15 & 4.97 & 5.43 & 4.63 & 4.00 & 5.10 \\
\hline Cystine (Cys) & 1.34 & 1.62 & 0.98 & 1.35 & 1.46 & 1.26 & - & 2.40 \\
\hline Methionine (Met) & 1.34 & 1.52 & 2.23 & 3.01 & 2.86 & 2.46 & - & 3.40 \\
\hline Total sulfur amino acids & 7.25 & 4.92 & 7.36 & 9.33 & 9.75 & 8.35 & 3.50 & 5.80 \\
\hline Leucine (Leu) & 6.38 & 9.06 & 9.74 & 9.75 & 10.12 & 8.77 & 7.00 & 8.80 \\
\hline Isoleucine (Ile) & 4.33 & 4.41 & 4.55 & 5.34 & 6.08 & 4.69 & 4.00 & 6.30 \\
\hline Lysine (Lys) & 4.79 & 2.23 & 9.36 & 5.95 & 5.10 & 4.75 & 5.50 & 7.00 \\
\hline Valine (Val) & 7.07 & 8.35 & 6.57 & 7.18 & 7.52 & 6.19 & 5.00 & 6.80 \\
\hline Tryptophan (Trp) & 1.37 & 0.55 & 0.87 & 0.59 & 0.94 & 1.93 & 1.00 & 1.50 \\
\hline Total & 40.96 & 36.37 & 48.17 & 47.38 & 49.29 & 43.52 & 36.00 & 51.2 \\
\hline \multicolumn{9}{|l|}{ Non-essential amino acids } \\
\hline Aspartic (Asp) & 10.94 & 12.25 & 7.31 & 7.74 & 7.11 & 7.69 & - & - \\
\hline Glutamic (Glu) & 18.00 & 10.75 & 19.75 & 19.24 & 21.00 & 19.42 & - & - \\
\hline Proline (Pro) & 5.47 & 4.82 & 8.71 & 9.35 & 9.50 & 9.62 & - & - \\
\hline Seine (Ser) & 5.69 & 3.75 & 4.18 & 4.25 & 1.20 & 5.99 & - & - \\
\hline Glycine (Gly) & 4.79 & 2.80 & 1.84 & 2.41 & 2.07 & 2.64 & - & - \\
\hline Alanine (Ala) & 5.24 & 7.28 & 3.30 & 3.25 & 3.07 & 3.85 & - & - \\
\hline Arginine (Arg) & 7.06 & 19.03 & 3.87 & 3.34 & 3.66 & 4.75 & - & - \\
\hline Histidine (His) & 1.85 & 2.95 & 3.23 & 3.04 & 3.10 & 2.52 & - & - \\
\hline Total & 59.04 & 63.63 & 52.19 & 52.62 & 50.71 & 56.48 & - & - \\
\hline
\end{tabular}

Total saturated fatty acids were the major group of fatty acids mainly due to the contribution palmitic acid, which corresponds to values higher than $63.69 \%$ to $64.06 \%$ total fatty acids in caramel and cocoa cheeses. Total unsaturated in caramel and cocoa spreadable cheeses, are represented amount ranging $35.13 \%$ to $35.60 \%$. Most of these unsaturated is monounsaturated fatty acids $30.89 \%$ and $31.44 \%$, respectively. Whereas, polyunsaturated in caramel and cocoa spreadable cheeses are $4.22 \%$ and $4.16 \%$, respectively. The linoleinc acid found is also less than $0.3 \%$ in caramel and cocoa spreadable cheeses.

The cocoa with walnut cheese was fairly higher in some fatty acids compared to caramel and cocoa cheeses. There was a marked difference between levels some of fatty acids in both of caramel and cocoa cheeses compared to cocoa walnut cheese. The most abundant saturated fatty acids were 
palmitic and stearic, whereas the main unsaturated fatty acids preset were oleic $(23.54 \% \pm 0.06)$ and linoleic $(19.51 \%$ \pm 0.23 ). The present investigates shown that the cocoa \& walnut cheese has a higher linoleic (C18:2 $\omega$ 6) and linolenic acid (C18:3 $\omega 3)$ compared to others two sample cheeses. Linolenic acid was found in a higher ratio $(4.01 \% \pm 0.04)$, while in caramel and cocoa cheese less than $0.3 \%$.

Short chain fatty acids (volatile fatty acids) (C6:0, C8:0, C10:0 and C12:0) were represented in Table (3), in appreciable amount in different goat cheese samples, which account as $8.5-9.5 \%$. These fatty acid chains and ratio were play and imparts role in improves flavor quality of sweet spreadable goat cheeses. These minor molecular fatty acids are pleasant in mouth feel of processed goat cheese. These results indicated by [30] short-chain free fatty acids play a significant role in the flavor of cheese. Mixtures of alkanoic acids with carbon chains from $\mathrm{C} 2$ to $\mathrm{C} 8$ or $\mathrm{C} 4$ to $\mathrm{C} 10$ appear to impart cheese-like flavors either to naturally maturing cheese or to flavor mixtures for processed cheese [31]. Short-chain fatty acids including butyric, caproic, and capric, which are formed from milk fat degradation, are considered among the necessary constituents of cheddar cheese flavor [32].

Cocoa with walnut cheese is containing a lower ratio of saturated acids corresponding to caramel and cocoa cheese (as total $51.21 \%$ ). Unsaturated fatty acids are higher in cocoa \& walnut cheese than other two cheeses (as total $48.78 \%$ ). Most of unsaturated were a PUFA at level $23.65 \%$. Surprisingly, the cocoa with walnut cheese was appreciable amounts of $\omega-6(19.5 \%)$ and $\omega-3$ (4.13\%) from the total of fatty acid profile, which are essential dietary fatty acids that cannot be synthesized by human but have to ingest. These acids play an important role in human growth, development and disease prevention. Epidemiological and clinical studies suggest that omega-3 PUFA found predominantly in marine organisms, may have beneficial effects in the prevention of several cardiovascular diseases [33]. According to the above mentioned, fortified sweet spreadable goat cheese with cocoa and walnut could be regarded as a good source for nutrient for human consumption tentatively for children feeding. The $\omega-6 / \omega-3$ ratio was at level $6.00,7.7$ and 4.7 contribute to caramel sweet cheese, cocoa sweet cheese, and cocoa with walnut cheese, respectively; this ratio is commonly used to assess the nutritional value and healthiness of food lipid material for human consumption [34]. [35] recommended that ratio $\omega-6 / \omega-3$ blew 4.0 in human diets to prevent the development of cardiovascular diseases and some chronic diseases including cancer.

Table 4. Nutritional evaluation of sweet spreadable goat cheese fortified with different flavors

\begin{tabular}{|c|c|c|c|c|c|c|}
\hline Parameters & Cocoa powder & Walnut & Goat milk & $\begin{array}{l}\text { Caramel sweet } \\
\text { spreadable } \\
\text { goat cheese. }\end{array}$ & $\begin{array}{l}\text { Cocoa sweet } \\
\text { spreadable } \\
\text { goat cheese }\end{array}$ & $\begin{array}{l}\text { Cocoa with } \\
\text { walnuts sweet } \\
\text { spreadable goat } \\
\text { cheese }\end{array}$ \\
\hline EAAI\% * & 73.08 & 65.32 & 81.40 & 82.96 & 88.70 & 80.19 \\
\hline Amino acid score $(\mathrm{CS})^{* *}$ & 42.21 & 31.85 & 55.34 & 39.33 & 62.70 & 64.13 \\
\hline \multicolumn{7}{|l|}{ Limiting amino acids } \\
\hline First & $\begin{array}{l}\text { Methionine } \\
+ \text { Cystine (42.21) }\end{array}$ & Lysine (31.85) & $\begin{array}{l}\text { Methionine } \\
+ \text { Cystine } \\
(55.34)\end{array}$ & $\begin{array}{l}\text { Tryptophan } \\
(39.33)\end{array}$ & $\begin{array}{l}\text { Tryptophan } \\
(62.70)\end{array}$ & $\begin{array}{l}\text { Methionine } \\
+ \text { Cystine (64.13) }\end{array}$ \\
\hline Second & Lysine (68.43) & Threonine (34.90) & $\begin{array}{l}\text { Tryptophan } \\
(58.00)\end{array}$ & $\begin{array}{l}\text { Methionine } \\
\text { +Cystine } \\
\text { (75.17) }\end{array}$ & $\begin{array}{l}\text { Methionine } \\
\text { +Cystine } \\
(74.48)\end{array}$ & Lysine (67.86) \\
\hline P-PER*** & 2.069 & 3.267 & 3.475 & 3.514 & 3.628 & 3.096 \\
\hline
\end{tabular}

*EAAI\%, essential amino acid index \%.

**CS, chemical score and first \& second limiting according to Block and Mitchell (1946) versus egg amino acid (\%)

***Predicted of protein efficiency ratio: (P-PER) according to Alsmeyer et al., (1974).

\subsection{Amino Acid Composition}

The amino acids compositions of sweet spreadable goat cheese are illustrated in Table (4) This table exerts that, Valine and Leucine acids were the most abundant essential amino acids in cocoa powder accounted 7.07 and 6.38 (g AA /16g nitrogen), respectively. Total aromatic amino acids and follows by the sum of sulfur containing amino acids were in the considerable amount of essential amino acids in cocoa powder (8.20 and $7.25 \mathrm{~g} \mathrm{AA} / 16 \mathrm{~g}$ nitrogen) and base of goat milk (9.72 and $7.36 \mathrm{~g} \mathrm{AA} / 16 \mathrm{~g}$ nitrogen).Both of Total aromatic amino acids and sum of sulfur containing amino acids in cocoa powder and goat milk were generally exceed their respective percentages stated in the egg amino acids reference and [19]. Leucine and valine were the most predominant amino acids founded in cocoa and caramel cheese. It could be investigated that, goat milk has a superior in Lysine content (9.36 g AA /16g nitrogen). Similar finding could be occurred in the caramel cheese and cocoa \& walnut sweet cheese in their essential amino acids compared to the egg amino acids reference and [19]. Amount of aromatic acids was lower in cocoa and walnut sweet cheese 8.84 (g AA $/ 16 \mathrm{~g}$ nitrogen).Cocoa sweet cheese is rich in leucine content (10.12 g AA $/ 16 \mathrm{~g}$ nitrogen), sulfur containing (9.75 g AA /16g nitrogen), total aromatic AA (9.75 g AA /16g nitrogen), isoleucine (6.08 g AA /16g nitrogen), these detected as essential amino acids and nutritionally is so superior. Defiantly, the cocoa sweet 
cheese was higher in total essential amino acids, corresponding to respect level in [19] by $136.98 \%$. Surprisingly, the sulfur content slightly increased in investigating cocoa cheese after using heat treatment into $9.75 \mathrm{~g} \mathrm{AA} / 16 \mathrm{~g}$ nitrogen. This slightly increases in sulfur containing could be attributed to breakdown and degradation of some other amino acids. These results were in agreement with [36]

The lysine and tryptophan levels in cheese's samples under this study are considerably lower than founded in the egg amino acids reference and [19], except one ratio of tryptophan in cocoa with walnut cheese (1.93 g AA /16g nitrogen). Asp and Glu acids (the amino acids with negatively charged side chain) were the most abundant in amino acid in cocoa powder. While, glutamic and proline followed by aspartic acids were the most abundant nonessential amino acid, found in goat (respectively as 19.75, 8.71 and 7.31) and processed different cheese under this current study.

Glutamic in the high ratio was 21.00 in cocoa spreadable cheese, followed by 19.42 in the walnut cheese. Pro content was in a higher ratio 9.62 ranked in cocoa walnut cheese and follows by cocoa spreadable sweet cheese. Cocoa spreadable sweet cheese was contained a drastically ratio of non- essential amino acids 50.71(g AA $/ 16 \mathrm{~g}$ nitrogen). Meanwhile, this Cocoa with walnuts spreadable sweet cheese was contained a perishable amount of non-essential amino acids 56.48 (g AA/16g nitrogen).

\subsection{Nutritional Quality Assessments of Sweet Spreadable Goat Cheese}

The calculated protein quality parameters investigated sweet spreadable goat cheeses are shown in Table 4 Essential amino acid index was ranged from 3.09 to $3.57 \%$. Cocoa sweet spreadable goat cheese had the highest chemical score $(88.70 \%)$, followed by the caramel sweet spreadable goat cheese $(82.96 \%)$, while the lowest value was that cocoa with walnuts sweet spreadable goat cheese $(80.19 \%)$. Protein quality (P-PER, CS, and EAAI \%) were diversely affected by different goat cheese formula. Cocoa with walnuts had a highest chemical score (CS) 64.13 followed by cocoa spreadable goat cheese $62.70 \%$. While the lowest CS found in caramel cheese $39.33 \%$. Generally, the cocoa cheese and coca with walnut cheese have a higher CS than found in the base of goat milk 55.34\% and walnut has a low in CS $31.85 \%$. Predicated protein efficiency ratio in investigating sweet spreadable goat cheese was correspondingly improved in cocoa and caramel cheese raged 3.5 to 3.62 . While, the P-PER of ingredients such as goat milk and cocoa powder was achieved as lower level compared to produce sweet goat cheese at 2.069 and 3.47 , respectively. Methionine + cystine are the first limiting amino acids in cocoa powder, goat milk and cocoa with walnut sweet cheese. Defiantly, the walnut limiting amino acids was limited in lysine as first amino acids. While, both of methionine + cystine are recorded as the second limiting amino acids in cheeses of caramel and cocoa sweet cheese. Tryptophan is the first limiting A.A. in caramel and cocoa sweet spreadable goat cheeses. Therefore, the lysine is accounted for the second limiting AA in cocoa with walnut cheese. This decreased in lysine in coca sweet spreadable walnut cheese is occurred to limiting lysine in walnut.

Table 5. Comparison between the essential amino acids content material substitute and components of different sweet cheese with those of FAO reference protein ( $\mathrm{mg} / \mathrm{gm}$ protein).

\begin{tabular}{|c|c|c|c|c|c|c|c|c|c|c|c|c|c|}
\hline \multirow[t]{2}{*}{$\begin{array}{c}\text { Essential } \\
\text { amino acids }\end{array}$} & \multirow[t]{2}{*}{$\begin{array}{c}\text { FAO } \\
\text { reference } \\
\text { protein } \\
(1973) \\
\end{array}$} & \multicolumn{2}{|c|}{ Walnut } & \multicolumn{3}{|c|}{ Cocoa Powder } & Goat Milk & \multicolumn{2}{|c|}{$\begin{array}{c}\text { Caramel } \\
\text { sweet } \\
\text { spreadable } \\
\text { goat cheese }\end{array}$} & \multicolumn{2}{|c|}{$\begin{array}{l}\text { Cocoa sweet } \\
\text { spreadable } \\
\text { goat cheese }\end{array}$} & \multicolumn{2}{|c|}{$\begin{array}{c}\text { Cocoa with } \\
\text { walnut sweet } \\
\text { spreadable } \\
\text { goat cheese }\end{array}$} \\
\hline & & $\mathrm{AA}^{*}$ & $\begin{array}{c}\text { AAS* } \\
*\end{array}$ & AA* & $\begin{array}{c}\mathrm{AAS}^{*} \\
*\end{array}$ & $\mathrm{AA}^{*}$ & $\begin{array}{c}\text { AAS* } \\
*\end{array}$ & $\mathrm{AA}^{*}$ & $\begin{array}{c}\text { AAS* } \\
*\end{array}$ & $\mathrm{AA}^{*}$ & $\begin{array}{c}\text { AAS* } \\
*\end{array}$ & $\mathrm{AA}^{*}$ & $\begin{array}{c}\mathrm{AAS}^{*} \\
*\end{array}$ \\
\hline Lysine & 55.0 & 22.3 & 40.55 & 47.9 & 87.0 & 93.6 & 170.1 & 59.5 & 108.2 & 51.0 & 92.7 & 47.5 & 86.4 \\
\hline Isoleucine & 40.0 & 44.1 & 110.2 & 43.3 & 108.0 & 45.5 & 113.7 & 53.4 & 133.5 & 60.8 & 152.0 & 46.9 & 117.3 \\
\hline Leucine & 70.0 & 90.6 & 129.4 & 63.8 & 91.0 & 97.4 & 139.1 & 97.5 & 139.3 & 101.2 & 144.6 & 87.7 & 125.3 \\
\hline $\begin{array}{l}\text { Methionine } \\
+ \text { Cystine }\end{array}$ & 35.0 & 31.3 & 89.43 & 26.8 & 77.0 & 32.1 & 91.71 & 43.6 & 124.6 & 43.2 & 123.4 & 37.2 & 106.3 \\
\hline $\begin{array}{l}\text { Phenylalanine }+ \\
\text { Tyrosine }\end{array}$ & 60.0 & 68.5 & 114.1 & 82.1 & 137.0 & 97.2 & 162.0 & 96.9 & 161.5 & 97.5 & 162.5 & 88.4 & 147.3 \\
\hline Threionine & 41.0 & 17.8 & 43.41 & 45.6 & 111.2 & 41.5 & 101.2 & 49.7 & 121.2 & 54.3 & 132.4 & 46.3 & 112.9 \\
\hline Tryptophan & 10.0 & 5.5 & 55.00 & 137 & 137.0 & 8.7 & 87.00 & 5.9 & 59.0 & 9.4 & 94.0 & 19.3 & 193.0 \\
\hline Valine & 50.0 & 83.5 & 167.0 & 70.7 & 141.4 & 65.7 & 131.4 & 71.8 & 143.6 & 75.2 & 150.4 & 61.9 & 123.8 \\
\hline
\end{tabular}

AA*: Amino acid (mg / gm protein).

AAS**: Amino acids score.

Table (5) shown the amino acids scores in different investigated sweet spreadable goat cheese and row martial in comparison to FAO reference protein (1973). Methionine + cystine and follows by tryptophan were the most limiting essential amino acids, in their ingredient. However, mixing goat milk and different ingredient could be improved their amino acids scores of producing sweet spreadable goat cheese. 


\subsection{Rheological Parameters by Texture Profile Analysis (TPA)}

Texture Profile Analysis (TPA) of spreadable fortified cheese as affected by type of flavoring: Data illustrated in Table (6) revealed that texture indices were at different levels of the variable of fortified flavor and procedures.
Firmness of spreadable cheese treatments were significantly increase in addition of caramel and cocoa with walnuts into cheese, which from 6.57 for control to 6.71 and 7.33. While, cocoa spreadable sweet cheese shown an appropriate decrease in firmness into 5.33 was recorded comparing to the control.

Table 6. Texture Profile Analysis (TPA) of sweet spreadable goat cheese fortified with different flavors

\begin{tabular}{|c|c|c|c|c|c|}
\hline Properties & Control & $\begin{array}{c}\text { Caramel spreadable } \\
\text { sweet cheese. }\end{array}$ & $\begin{array}{c}\text { Cocoa spreadable } \\
\text { sweet cheese }\end{array}$ & $\begin{array}{c}\text { Cocoa and walnut } \\
\text { sweet cheese }\end{array}$ & Probability \\
\hline Firmness & $6.57^{\mathrm{b}} \pm 0.14$ & $6.71^{\mathrm{b}} \pm 0.410$ & $5.35^{\mathrm{C}} \pm 0.130$ & $7.33^{\mathrm{a}} \pm 0.45$ & $\mathrm{SN}^{* *}(\mathrm{p}<0.05)$ \\
\hline Cohesiveness & $0.225^{\mathrm{c}} \pm 0.011$ & $0.308^{\mathrm{bc}} \pm 0.028$ & $0.379^{\mathrm{b}} \pm 0.097$ & $0.633^{\mathrm{a}} \pm 0.13$ & $\mathrm{SN}(\mathrm{P}<0.05)$ \\
\hline Gumminess & $1.47^{\mathrm{b}} \pm 0.042$ & $1.59^{\mathrm{b}} \pm 0.074$ & $1.84^{\mathrm{a}} \pm 0.053$ & $1.99^{\mathrm{a}} \pm 0.18$ & $\mathrm{SN}(\mathrm{P}<0.05)$ \\
\hline Chewiness & $0.41^{\mathrm{b}} \pm 0.034$ & $0.46^{\mathrm{b}} \pm 0.003$ & $0.88^{\mathrm{a}} \pm 0.021$ & $0.78^{\mathrm{a}} \pm 0.88$ & $\mathrm{SN}(\mathrm{P}<0.05)$ \\
\hline Springiness & $0.27^{\mathrm{a}} \pm 0.014$ & $0.37^{\mathrm{a}} \pm 0.100$ & $0.46^{\mathrm{a}} \pm 0.004$ & $0.38^{\mathrm{a}} \pm 0.11$ & $\mathrm{NS} * * *$ \\
\hline Resilience & $0.077^{\mathrm{a}} \pm 0.029$ & $0.067^{\mathrm{b}} \pm 0.042$ & $0.031^{\mathrm{b}} \pm 0.003$ & $0.095^{\mathrm{b}} \pm 0.08$ & NS \\
\hline
\end{tabular}

Any two means in the same row followed by the same letter are not significantly $(\mathrm{P} \geq 0.05)$ different according LSD test

$\mathrm{SN}^{* *}$ : is significant at $\mathrm{p}<0.05$

NS***: is non-significt at probability $\mathrm{p}<0.05$

Cohesiveness values ranged from 0.225 to 0.633 showed significant variation between different types of fortified spreadable cheese treatments. Their significance $(p<0.05)$ higher cohesiveness value was recorded of cocoa with walnuts sweet cheese treatment followed by caramel and cocoa sweet spreadable goat cheese appreciable differences between them. The cohesiveness of the rheological parameters is correlated with the properties of a food as it is swallowed, especially if it is in solid state [37].

Gumminess and chewiness of different fortified sweet goat cheese treatments ranged from 1.47 to 1.99 and 0.41 to 0.88 , respectively showed significant $(p<0.05)$ different between control goat cheese sample and caramel spreadable sweet cheese; cocoa spreadable sweet cheese and cocoa and walnut sweet cheese. According to [38] gumminess determines the force required to chew a semi-solid food. The parameter of gumminess presented a higher value for the formulation with cocoa, sugar, caramel and walnut.

Gumminess of coca with walnut cheese was significantly $(p<0.05)$ increased by replacement of added walnuts and cocoa with control goat cheese, which increase from 1.47 for control goat cheese to 1.99 in cocoa with walnut cheese. Springiness has also been found meaningfully related to sensory springiness (or elasticity). The partial replace with walnuts in goat cheese is non-significant $(p \geq 0.05)$ difference in the Springiness of different formula. The partial replacement of walnuts fat with goat cheese could be able to increase resilience from 0.077 for control goat cheese to 0.095 in cocoa \&walnut cheese. Otherwise, there were non significant differences between types of formula cheese each others. These results were in line with the results of sensory evaluation which obtained by panelists.

\subsection{Effect of Caramel, Cocoa and Cocoa with Walnuts on the Microstructure of Sweet Spreadable Goat Cheese}

Seen from microscopic investigation, different additives volume of ingredients had certain linkage matric of sweet goat cheese (Fig 1). Caramel sweet goat cheese seems to control goat cheese with a good dispersion in bondage of fat particulate highly scatter in the hydrated wrapped casein mixture. Similar seems to cocoa spreadable sweet goat cheese. It could be found a uniform structure of casein, disappear much of fat globule. Whereas, the cocoa powder is effect on color of sweet goat cheese comparable to control goat cheese. According to the most appropriate cocoa with walnut, the test compared to the color and mixture formulation had effect in decrease casein net formed and shows a higher granules in casein, and fat globule beside cocoa molecules. There was a gradually increase in volume of processed cocoa with walnuts cheese. Regarding to the microscopic investigation founded that, the caramel sweet spradable goat cheese and cocoa with walnut sweet spreadable goat cheese is more effect on microstructure and in appearance than occurred in cocoa sweet spreadable goat cheese.

\subsection{Microbiological Assessment}

Table (7) showed the microbiological analysis of sweet spreadable goat cheese with different flavors, caramel, cocoa and cocoa with walnuts .It can be observed that, different treatments had a low total bacterial count that ranged from 115 to $187 \mathrm{cfu} \mathrm{g}^{-3}$ when fresh and from 205 to $312 \mathrm{cfu} \mathrm{g}^{-3}$ after 3 months. The low total bacterial count of sweet spreadable goat cheese with different flavors can be attributed to the high heat treatment received during processing $\left(85^{\circ} \mathrm{c} / 15\right.$ mints) and to the hygienic conditions during processing, handling and packing in sterilized packs [39].

This was also apparent from the absence of total coliform count, yeasts and moulds, Bacillus cereus, Lesteria, and staph aurous. From the same table it could be observed that the spore form bacterial count were low when fresh and during storage period. These results are similar to report by [40]. The phenolic compound in cocoa has a 
potential in prevention of food spoilage and contamination with Listeria momocytogene, and also agreed with those given by [41], [42]. This indicated that the prepared sweet spreadable goat cheese fortified with different flavors had good microbiological quality when fresh and during storage. Activity of certain long-chain fatty acids have long been known to inhibit microorganisms, especially gram positive bacteria. Thus assume that other components contained in cocoa , fat of goat milk, and walnut lipid, such as fatty acids as monounsaturated and unsaturated and saturated fatty acids, were likely responsible for antibacterial effects . This result is in agreement by [40] Phenolic compound in

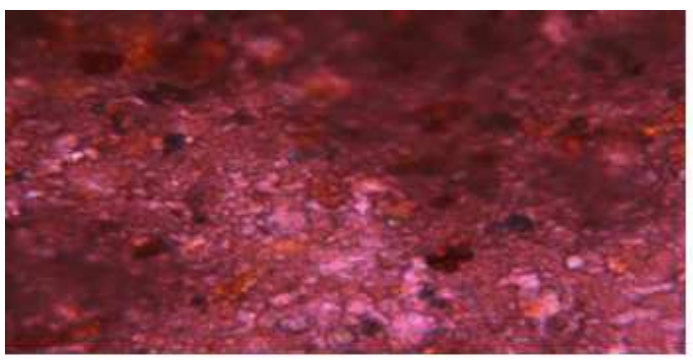

(a)Control goat cheese

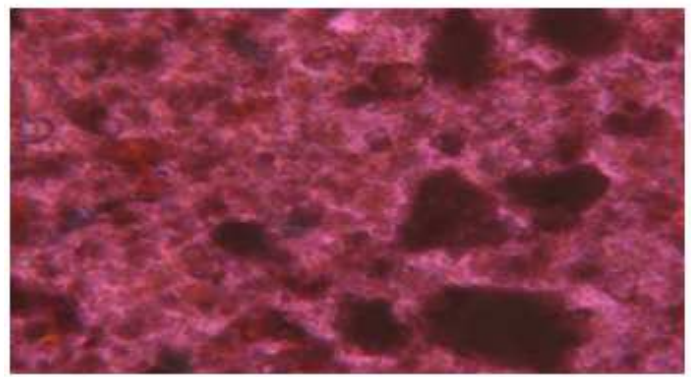

(c)Cocoa spreadable sweet goat cheese cocoa powder is richening in flavanol monomers (catachin and epicatechin) and procyanidin oligomers [43]. Bioactive Compounds are the naturally occurring chemical compounds contained in, or derived from, a plant, animal or marine source, that exert the desired health/wellness benefit. Functional Ingredients are the standardized and characterized preparations, fractions or extracts containing bioactive compounds of varying purity, that are used as ingredients by manufacturers in the food [44].Antimicrobial activity of cocoa polyphenols, against oral streptococci [45].

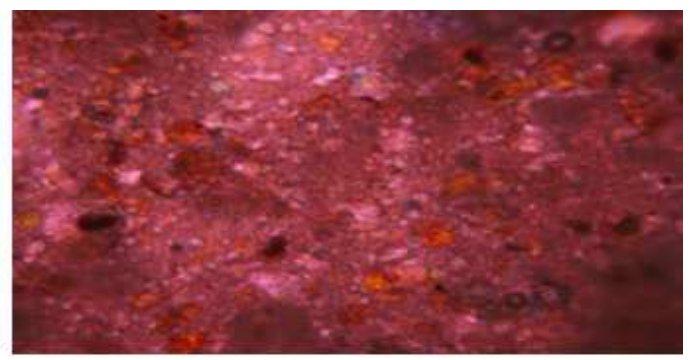

(b)Caramel spreadable sweet goat cheese

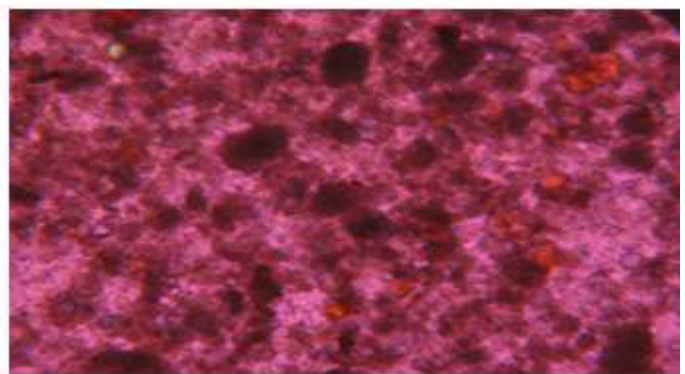

(d)cocoa and Walnuts spreadable sweet goat cheese

Figure 1. Effect of caramel, cocoa and walnuts lon the microstructure of sweet spreadable goat cheese.

Table 7. Microbiological analysis of sweet spreadable goat cheese.

\begin{tabular}{|c|c|c|c|c|c|c|c|c|}
\hline Treatments & $\begin{array}{l}\text { Storage } \\
\text { period } \\
\text { (Month) } \\
\end{array}$ & $\underset{3}{\text { T.B.C }} \mathbf{c f u} / \mathbf{1 0}^{-}$ & T.C.C. & $\begin{array}{l}\text { Spore } \\
\text { form } \\
\text { cfu } / \mathbf{1 0}^{-1}\end{array}$ & $\begin{array}{l}\text { Yeast and } \\
\text { Molds }\end{array}$ & $\begin{array}{c}\text { Bacillus } \\
\text { cereus }\end{array}$ & Listeria spp. & $\begin{array}{l}\text { Staph. } \\
\text { Aureus }\end{array}$ \\
\hline \multirow{4}{*}{$\begin{array}{l}\text { Caramel sweet } \\
\text { spreadable goat } \\
\text { cheese }\end{array}$} & Fresh & 1.15 & ND & 1.0 & ND & ND & ND & ND \\
\hline & 1 & 1.69 & ND & 1.8 & ND & ND & ND & ND \\
\hline & 2 & 1.99 & ND & 2.3 & ND & ND & ND & ND \\
\hline & 3 & 2.05 & ND & 2.9 & ND & ND & ND & ND \\
\hline \multirow{4}{*}{$\begin{array}{c}\text { Cocoa } \\
\text { sweet spreadable } \\
\text { goat cheese }\end{array}$} & Fresh & 1.87 & ND & 1.4 & ND & ND & ND & ND \\
\hline & 1 & 2.10 & ND & 1.9 & ND & ND & ND & ND \\
\hline & 2 & 2.80 & ND & 2.4 & ND & ND & ND & ND \\
\hline & 3 & 3.12 & ND & 3.2 & ND & ND & ND & ND \\
\hline Cocoa with & Fresh & 1.41 & ND & 1.1 & ND & ND & ND & ND \\
\hline Walnuts Sweet & 1 & 1.73 & ND & 1.7 & ND & ND & ND & ND \\
\hline spreadable goat & 2 & 1.98 & ND & 2.4 & ND & ND & ND & ND \\
\hline cheese & 3 & 2.09 & ND & 3.3 & ND & ND & ND & ND \\
\hline
\end{tabular}

T.B.C : Total bacterial count.

T.C.C. : Total coliform count

\subsection{Sensory Evaluation for Sweet Spreadable Goat Cheese}

Sweet spreadable cheese from different treatments using caramel, cocoa and cocoa with walnuts obtained high scores (Table 8). The aroma and flavor were acceptable in all formulas, although that the products made from goat milk which is not acceptable for many people due to its gouty flavor. This is regards to the interaction for sweet, 
acidity and different added flavor .From the same table we can also observed that the body and texture for sweet spreadable goat cheese were increased by fortified with cocoa with walnuts, caramel and lastly cocoa. The same trend can be noticed in the outer and appearance in all formulas. These results were parallel with the results of rheological parameters. The total scores gained generally slightly decreased by the advancing of storage period in all treatments.

Table 8. Sensory evaluation of sweet spreadable goat cheese after different storage period at room temperature

\begin{tabular}{|c|c|c|c|c|}
\hline \multirow{2}{*}{$\begin{array}{l}\text { Storage period } \\
\text { (Month) }\end{array}$} & \multirow[b]{2}{*}{ Character assessed } & \multicolumn{3}{|c|}{ Treatments } \\
\hline & & $\begin{array}{c}\text { Caramel spreadable sweet } \\
\text { cheese } \\
\end{array}$ & Cocoa spreadable cheese & $\begin{array}{c}\text { Cocoa with Walnuts } \\
\text { spreadable cheese }\end{array}$ \\
\hline \multirow{5}{*}{ Fresh } & $\mathrm{A} \& \mathrm{~F}^{*}(40)$ & $38 \mathrm{a}$ & $36 a$ & $38 a$ \\
\hline & $\mathrm{B} \& \mathrm{~T}^{* *}(40)$ & $\begin{array}{l}30 \mathrm{a} \\
38 \mathrm{a}\end{array}$ & $36 a$ & $38 a$ \\
\hline & O.A $* * *(20)$ & $\begin{array}{l}50 \mathrm{a} \\
18 \mathrm{a}\end{array}$ & $\begin{array}{l}50 \mathrm{~d} \\
18 \mathrm{a}\end{array}$ & $\begin{array}{r}58 \mathrm{a} \\
18 \mathrm{a}\end{array}$ \\
\hline & Total & $\begin{array}{l}10 \mathrm{~d} \\
95\end{array}$ & $\begin{array}{l}10 \mathrm{a} \\
90\end{array}$ & $\begin{array}{c}18 \mathrm{a} \\
95\end{array}$ \\
\hline & 100 & & & \\
\hline \multirow{5}{*}{1} & A\&F (40) & $37 a$ & $36 a$ & $37 \mathrm{a}$ \\
\hline & B\&T (40) & $38 \mathrm{a}$ & $36 a$ & 38 \\
\hline & O.A (20) & $\begin{array}{l}50 \mathrm{a} \\
19 \mathrm{a}\end{array}$ & $17 \mathrm{a}$ & $\begin{array}{cc}30 \mathrm{~d} \\
19 a^{2}\end{array}$ \\
\hline & Total & 94 & 80 & $19 a$ \\
\hline & 100 & & 89 & 94 \\
\hline \multirow{5}{*}{2} & $\mathrm{~A} \& \mathrm{~F}(40)$ & & & \\
\hline & B\&T (40) & 38 & 630 & $3 / \mathrm{a}$ \\
\hline & O.A (20) & $\begin{array}{l}38 \mathrm{a} \\
18 \mathrm{a}\end{array}$ & $03 a$ & $38 \mathrm{a}$ \\
\hline & Total & $18 \mathrm{a}$ & $1 / 9$ & $18 \mathrm{a}$ \\
\hline & 100 & 92 & 88 & 93 \\
\hline \multirow{5}{*}{3} & $\mathrm{~A} \& \mathrm{~F}(40)$ & & & \\
\hline & B\&T (40) & $\begin{array}{l}50 \mathrm{a} \\
37 \mathrm{a}\end{array}$ & $35 \mathrm{a}$ & $30 d$ \\
\hline & O.A (20) & $3 / \mathrm{a}$ & $5 \mathrm{da}$ & $3 / \mathrm{a}$ \\
\hline & Total & $18 \mathrm{a}$ & $\begin{array}{c}88 \\
88\end{array}$ & $18 \mathrm{a}$ \\
\hline & 100 & 91 & 88 & 91 \\
\hline
\end{tabular}

*A\&F: Aroma \&Flavor- **B\&T: Body \&Texture - ***O.A: outer appearance.

Means denoted within the same row without different superscripts are significantly different at $\mathrm{P}<0.05$.

\subsection{Economical Evolution}

The calculated cost per $\mathrm{Kg}$ (LE) of the resultant sweet spreadable cheese with different flavors Caramel, Cocoa and Cocoa with walnuts in table (9) indicated that the use of goat cheese curd as the main component in flavored sweet spreadable cheese lowered the cost compared to the cost of the like this products in the local market (neutella) which cost 87.5 LE per one $\mathrm{Kg}$, while it cost $14.1,16.8$ and 22.2 LE per one $\mathrm{Kg}$ for Caramel, Cocoa and Cocoa With Walnuts Sweet Spreadable Cheese respectively.

Table 9. Costs in LE of used ingredients in sweet spreadable goat cheese fortified by flavors.

\begin{tabular}{|c|c|c|c|c|}
\hline \multirow[b]{2}{*}{ Ingredients } & \multirow[b]{2}{*}{ Price per Kg (LE) } & \multicolumn{3}{|c|}{ Costs of blend / kg (LE) } \\
\hline & & $\begin{array}{c}\text { Caramel Sweet } \\
\text { Spreadable Cheese }\end{array}$ & $\begin{array}{c}\text { Cocoa Sweet } \\
\text { Spreadable Cheese }\end{array}$ & $\begin{array}{c}\text { Cocoa with Walnuts Sweet } \\
\text { Spreadable Cheese }\end{array}$ \\
\hline Goat's milk & 3.50 & 5.5 & 5.09 & 4.73 \\
\hline Cocoa powder & 40.0 & & 3.08 & 2.86 \\
\hline Sugar & 5.5 & 0.92 & 0.85 & 0.79 \\
\hline Walnuts & 75,0 & -- & --- & 5.34 \\
\hline Emulsifying & 140.0 & 0.85 & 0.82 & 0.78 \\
\hline Starter & 5400 & 4.50 & 4.30 & 4.00 \\
\hline Total cost of used ingredients & & 11.77 & 14.14 & 18.5 \\
\hline
\end{tabular}

$10 \%$ direct costs (pack \& sticker) , 10\% indirect costs (workers, electricity, extra.....)

\section{Conclusions}

From the present study, it could be recommended goat cheese fortified by flavors, caramel, cocoa and cocoa with walnuts, to produce sweet spreadable goat cheese as economic products, with high nutritional value, healthy potential benefits, and gained high scores in organoleptic properties.

\section{References}

[1] Meyer, A., 1973. Processed cheese manufacture. (1 ST ed.) Food trade press LTd., London, UK.

[2] Kosikowski, F. V. and V. V. Mistry, 1997a. Bakers', Neufchatel, Cream, Quark, and Ymer. Cheese and Fermented Milk Foods - Origins and Principles, Volume 2, 3rd edn., pp. 147-161, F.V. Kosikowski, L. L. C., Westport. 
[3] Schulz-Collins, D. and B. Senge, 2004. Acid- and acid/rennet-curd cheeses, part A.: Quark, cream cheese and related varieties. Cheese Chemistry, Physics and Microbiology - Major Cheese Groups, (eds. P. F. Fox, P. L. H.McSweeney, T. M. Cogan \& T. P. Guinee), 3rd edn. Volume 2, pp. 301-328, Elsevier Academic Press, Amsterdam.

[4] FAO/WHO ,2007e. Codex standard for cream cheese, CODEX STAN 275-1973. Codex Alimentarius Milk and Milk Products, pp. 158-164, Communication Division FAO, Rome. (www.codexalimentarius.net/web/standard list).

[5] Guo B. H., 2004 .Modern dairy products processing technology-cheese [M]. Beijing: Chemical Industry Press, 32. (In Chinese)

[6] Subramanian, R., K. Muthukumarappan and S. Gunasegaram, 2006. Linear viscoelastic properties of regular- and reduced-fat pasteurized process cheese during heating and cooling. International Journal of Food Properties, 9: 377-393.

[7] Georgia D., S., and A. Thomareis, 2008. Effect of chemical composition on the linear viscoelastic properties of spreadable-type processed cheese. Journal of Food Engineering 84: $368-374$

[8] Minife, B. W., 1989. Chocolate, cocoa and confectionary (3rd Ed.). London: Chapman and Hall.

[9] Rambali, B., I. Van Andel, E. Schenk, G. Wolterink, G. Van de Werken, H. Stevenson and W. Vleenming, 2002. The contribution of cocoa additive to cigarette smoking addiction. RIVM report 650270002 .

[10] Morgan, J., 1994. Chocolate: A flavour and texture unlike any other. American Journal of Clinical Nutrition, 60(6):1065-10675.

[11] Blomhoff R., M. H. Carlsen, L.F . Andersen and D. R., Jacobs ,2006. Health benefits of nuts: potential role of antioxidants. Br J Nutr 96(S2):S52-S60

[12] Mexis S.F., A. V. Badeka , K.A . Riganakos, K. X. Karakostas, and M. G. Kontominas ,2009. Effect of packaging and storage conditions on quality of shelled walnuts. Food Control 20(8):743-751

[13] Oliveira R, M. Fátima Rodrigues, and M. Gabriela Bernardo-Gil (2002) Characterization and supercritical carbon dioxide extraction of walnut oil. J Am Oil Chem Soc 79(3):225-230.

[14] Gharibzahedi S.M.T., S.M. Mousavi, M .Hamedi, and F. Khodaiyan ,2011. Determination and characterization of kernel biochemical composition and functional compounds of Persian walnut oil. Journal of Food Science and Technology http://www.springerlink.com/ content/07532j13544rn811/ (Accessed on 13th, November, 2011)

[15] Mariela M. T., L. M. Marcela and M.I. Damián ,2005. A Multivariate Study of the Relationship Between Fatty Acids and Volatile Flavor Components in Olive and Walnut Oils. JAOCS, Vol. 82, no. 2 :105-110.

[16] Pereira, .JA., I. Oliveira, A. Sousa, I. C. Ferreira, A. Bento and L. Estevinho 2008. Bioactive properties and chemical composition of six walnut (Juglans regia L.) cultivars. Food Chem Toxicol 46 (6):2103-2111.
[17] AOAC, 2012. Official Methods of Analysis. 19th ed. Gaithersburg, MD: AOAC International.

[18] Miller E. L. ,1967. Determination of the tryptophan content in feeding stuffs with particular reference to cereals. J. Sci. Food Agric., 18:381-386.

[19] FAO/WHO/UNU ,1985. Energy and protein requirement . WHO technical Reporte Series NO.724, World Health Organization Geneva.

[20] Mente, E., P. Coutteau, Dominic Houlihan, I. Davidson and P. Sorgeloos ,2002. Protein turnover, amino acid profile and amino acid flux in Juvenile Shrimp Litopenaeus Vannamei: Effects of dietary protein source. The Journal of Expermintal Biology. 205:3107-3122.

[21] Hidvégi, M., and F. Bekes ,1984. Mathematical modeling of protein quality from amino acid composition. Proc. Int. Assoc. Cereal Chem. Symp. Ed ., by R. Lasztity and M, Hidvégi, p. 205. Akademiai Kiad Budapest (cited from Mubarak (2001), Nahrung / Food , 45 (4):241-245.

[22] Alsmeyer R. H., A. E. Cunningham and M. L. Happich, 1974. Equations predict PER from amino acid analysis. Food Technol. (7): 34-38.

[23] Bourne, M. C. , 2003. Food texture and viscosity: concept and measurement. Elsevier Press, New York/ London

[24] Marshall, T. R. ,1993. Standard methods for the examination of dairy production. 16 th ed Am. Publ. Health Assoc., Inc ., Washington, D.C.

[25] SAS, 2008. SAS/STAT software for PC. Release 9.2. Cary, NC, USA: SAS Institute Inc.

[26] Park, Y.W., 2006. Goat milk. Chemistry and nutrition. In: Park, Y.W., Haenlein, G.F.W. (Eds.), Handbook of Milk of Nonbovine Mammals. Blackwell Publishing, Oxford, pp. 34-58.

[27] Lo'pez-Aliaga, I., M.J.M. Alfe' rez, M. Barrionuevo, T. Nestares, M. R. Sanz Sampelayo, M.S. Campos ,2003. Study of nutritive utilization of protein and magnesium in rats with resection on the distal small intestine. Beneficial effect of goat milk. Journal of Dairy Science 86:2958-2966.

[28] Marchesseau, S., E. Gastaldi, A. Lagaude et al., 1997. Infleuence of $\mathrm{pH}$ on protein interactions and microstructure of process cheese [J]. J Dairy Sci., 80:1483-1489.

[29] Liu L., P.Howe, Y. Zhou, Z. XU, C. Hocart and R. Zhanga ,2000. Fatty acids and b-caroteine in Australian purslane (Porttulaca oleracea) varieties . J. Chromatogr. A 893, 207-213.

[30] Jeon, I. J., 1994.. Chemistry of dairy lipids. Review of free fatty acids. ACS Symp. Ser. 558:196-207.

[31] Law, B. A.,1985. Advances in Microbiology and Biochemistry of Cheese and Fermented Milk. F. L. Davies, F. L. and B. Law, eds. Elsevier Applied Science, London, UK.

[32] Urbach, G. ,1997. The flavor of milk and dairy products: II. Cheese: contribution of volatile compounds. Int. J. Food Technol. 50:79-89.

[33] Davis, L. W. Stonehouse, and D. T. Loots, J. MukuddemPetersen, F. Van der Westhuizen, S. J. Hanekom and J. C. Jerling, 2007. The effect of high walnut and cashew nut diets on the antioxidant status of subjects with metabolic syndrome. Eur. J. Nut. 46: 155-164. 
[34] Simopoulos, A. p.,2004. Omega-6/omega-3 essential fatty acid ratio and chronic diseases. Food Reviews International 20:77-90.

[35] Raes, K. , S. Desmet, and D. Demeyer ,2004. Effect of dietary fatty acids on incorporation of long chain fatty acids and conjugated linoleic acid in lamb beef and pork meat: a review. Animal Feed Sci. and Technology 113:199-221.

[36] Khattab, R.Y., S. D. Arntfield and C. M. Nyachoti, 2009. Nutritional quality of legume seeds as affected by some physical treatments, part1: protein quality evaluation. LWTFood Sci. and Technology.42: 1107-1112.

[37] Ishihara, S., M. Nakauma, T. Funami, , S. Odake, , and K. Nishinari, 2011. Viscoelastic and fragmentation characters of model bolus from polysaccharide gels after instrumental mastication. Food Hydrocolloids, 25: 1210-1218

[38] Oliveira, L. F., S. V. Borges, J. Nascimento, A. C. Cunha, T. B. Jesus and P. A. P. Pereira, 2009. Use banana Peel in the production of banana candy bulk-quality assessment. Food and Nutrition 20(40): 581-589.

[39] Abd Rabow, F. H, A.M. Abd El Fattah, M.M. El sayed and A.G. Mohamed , 2005. Improved of nutritional value of processed cheese by using modified emulsifying salts. Egypt.
J. Dairy sci. (33): $85-103$.

[40] Marina Bubonja-Sonje , Jasminka Giacometti and Maja Abram ,2011. Antioxidant and antilisterial activity of olive oil, cocoa and rosemary extract polyphenols. Food Chemistry 127: 1821-1827.

[41] Saleem R. M., and N. A. Dosh ,2007. Inversion of local soft sheep's cheese to hulloun cheese. Proc. 10 th Egyption Conference Dairy Sci., Technology. 443-449.

[42] Williams, M. R., and R. Syson, 1984. The bacteriological quality of Cyprus cheese, Environmental Heath, 92:146.

[43] Wollgast, J., and E. Anklam, 2000. Review on polyphenols in Theobroma cacao: Changes in composition during the manufacture of chocolate and methodology for identification and quantification. Food Research International, 33(6): 423-447.

[44] Dixon, Richard, A. and L. Christopher ,1999. Flavonoids and Isoflavonoids-A Gold Mine for Metabolic Engineering. Trends in Plant Science, 4: 394-400.

[45] Smullen, J., G. A. Koutsou, H. A. Foster, A. Zumbe, and D. M. Storey, 2007. The antibacterial activity of plant extracts containing polyphenols against Streptococcus mutans. Caries Research, 41(5):342-349. 